\title{
RADIOCARBON DATING IN THE VERNADSKY INSTITUTE I-IV
}

A. P. VINOGRADOV, A. L. DEVIRTS, E. I. DOBKINA, and N. G. MARKOVA

V. I. Vernadsky Institute of Geochemistry and Analytical Chemistry, Academy of Sciences, USSR, Moscow

Results of absolute age determination by the radiocarbon method, obtained in the Radiocarbon Laboratory of the Vernadsky Institute are given in this article. The counting of natural $\mathrm{C}^{14}$ activity was realized by measuring the gaseous carbon compounds- $\mathrm{CO}_{2}$ and $\mathrm{C}_{2} \mathrm{H}_{6}$-with the aid of a proportional counter. Investigation objects were wood, peat, coal, plant and animal remains and other organic material. All samples were preliminarily treated with hot $2 \% \mathrm{NaOH}$ and $5 \% \mathrm{HCl}$ to remove foreign humic acid and carbonate. Carbon dioxide, which was obtained after burning, was freed of electronegative admixtures by purification with the aid of $\mathrm{CaO}$. Ethane was synthesized from the sample carbon through the following stages: natural sample $\rightarrow \mathrm{CO}_{2} \rightarrow \mathrm{CaCO}_{3} \rightarrow \mathrm{CaC}_{2} \rightarrow$ $\mathrm{C}_{2} \mathrm{H}_{2} \rightarrow \mathrm{C}_{2} \mathrm{H}_{6}$. The counting gas was let into the counter up to a pressure of $2 \mathrm{~atm}$. Counters of stainless steel or copper of different volumes from 0.5 to 2 litres were used. The screening of the counters was effected by steel (24 cm thick) and mercury $(2.5 \mathrm{~cm}$ thick) shields; the counter together with the mercury shield was enclosed in a circle of Geiger counters of the GS-60 type arranged in anti-coincidence. A detailed description of the methods, the constructions and the apparatus has been published (Vinogradov, Devirts, Dobkina, Markova, Martishchenko, 1961).

At the present time the background of a copper counter with a working volume of $1.5 \mathrm{~L}$, at a pressure of $2 \mathrm{~atm}$ for $\mathrm{CO}_{2}$, is 6.3 counts/ min, the standard counting 16.0 counts $/ \mathrm{min}$. The ethane measurement in a similar counter is carried out in a steel chamber, where besides the mentioned shielding an additional screen of a paraffin and boric acid mixture is established, the background in this case being 8.7 counts $/ \mathrm{min}$, the standard counting 36.5 counts/min. Each sample was measured twice, the measurement duration was ca. $24 \mathrm{hr}$, or $48 \mathrm{hr}$ if necessary.

Wood from a thirty-year-old birch which had been felled in 1908 in Kamtchatka was used as a recent standard. For the verification of the recent standard it was compared with oxalic acid from the U.S. Natl. Bureau of Standards, which we had at our disposal. The oxalic acid activity, multiplied by a coefficient 0.95 , coincided with the activity of our recent standard. All datings, given in this article, are calculated on the basis of the value of $\mathrm{C}^{14}$ half-life, which is $5568 \pm 30 \mathrm{yr}$. As all ages in the present collection of papers were calculated as years before A.D. 1950, we have where necessary counted anew the previously published data, chiefly for archaeological and some geological samples of young age. For the elucidation of possible $\mathrm{C}^{14}$ variations in the past we carried out a mass-spectrometric analysis of the $\mathrm{C}^{13} / \mathrm{C}^{12}$ value in $\mathrm{CO}_{2}$ from fossil 
samples of various ages, up to 35,000 B.P. The isotopic ratio values were compared with the $\mathrm{C}^{13} / \mathrm{C}^{12}$ values in the contemporary standard. No considerable deviations were noted; therefore for the samples below a correction for $\Delta \mathrm{C}^{14}=2 \delta \mathrm{C}^{13}$ was not introduced. Absence of isotopic fractionation in the synthesis of ethane has also been established with the aid of mass-spectrometric determinations.

The chief line of investigations was connected with the subject "Paleogeography and chronology of the Upper Pleistocene and Holocene in the north-western European part of the USSR". The work was carried out together with the Geographical Institute of the Academy of Sciences, the scientific workers of which collected the material. A detailed consideration and interpretation of the results obtained was published in the Collected Papers to the VIIth Congress of INQUA which took place in August 1965, in USA (Paleogeography and Chronology of the Upper Pleistocene and Holocene According to Data of the Radiocarbon Method, 1965).

Most of the datings below were published by the authors in 4 communications (Vinogradov, Devirts, Dobkina, Markova, Martishchenko, 1956; the same authors, 1959; Vinogradov, Devirts, Dobkina, Markova, 1962; the same authors, 1963); some datings are published for the first time.

The sample descriptions were kindly given by specialists who collected the samples; the authors express their thanks to them.

\section{SAMPLE DESGRIPTIONS}

\section{GEOLOGICAL SAMPLES}

\section{A. Peat and lake deposits of the Holocene}

The material was selected from a series of key sections of peat bogs from the territory of the central and NW regions of the Russian plain.

The formation of these peat deposits dates from the disappearance of the last (Valdai) glaciation from the mentioned territory. The data obtained must characterize the time of retreat of the ice sheet and the evolutionary history of peat deposits in the Holocene-establishment of the chief stages of the vegetative cover and the climatic conditions. In addition, one other peat deposit from territories near the Black Sea was investigated, the well-known Imnat bog. The great thickness of its peat layers spans the history of Holocene events in the Caucasus. The sampling in each section was carried out layer by layer, taking into account the stratigraphy of the whole thickness of the peat deposit. Usually 5-10 samples were selected, as far as possible on the boundaries of vegetative zones, in order to establish the duration of each climatic phase.

Preliminary age estimations (before $\mathrm{C}^{14}$ dating) are given on the basis of the pollen-and-spore analysis. 


\section{Shuvalovo Peat Bog series}

The Shuvalovo peat bog is located on the northern outskirts of the city of Leningrad $\left(60^{\circ} 00^{\prime} \mathrm{N}\right.$ Lat, $30^{\circ} 20^{\prime} \mathrm{E}$ Long). The choice of the Shuvalovo deposit as well as of the following-the Osechenski mokh-was determined by the fact that these peats were widely known and may be considered as classical examples of high peat bog types, such as are characteristic of the central and NW regions of the European part of USSR. Sampling of the Shuvalovo peat bog was carried out from an open exposure in the $\mathrm{N}$ part of the peat bog, where the deposit is exposed down to the mineral substratum. The general thickness of the peat deposits was $3.18 \mathrm{~m}$; they are underlain by sands with clay intercalations. Samples were coll. 1962 and subm. by M. I. Neistadt (Geog. Inst. of the Acad. Sci., USSR).

\section{Mo-319. Shuvalovo}

$3200 \pm 190$

Sphagnum peat, decomposition degree $5-10 \%$, taken from a depth of 1.30 to $1.35 \mathrm{~m}$. The supposed age is 2500 to $3000 \mathrm{yr}$.

\section{Mo-320. Shuvalovo}

$4820 \pm 260$

2870 в.c.

Woody cotton-grass peat, border horizon, decomposition degree $50-60 \%$, sampling depth 1.70 to $1.75 \mathrm{~m}$. The supposed age is 5000 to 5500 yr. In this horizon a great amount of root, stump, stem remains are met. The age of pine wood from this horizon (Mo-325) was also determined.

\section{Mo-321. Shuvalovo}

$7790 \pm 265$

Woody cotton-grass peat, decomposition degree $55-60 \%$, sampling depth 2.10 to $2.15 \mathrm{~m}$. The supposed age is 7500 to $8000 \mathrm{yr}$.

\section{Mo-322. Shuvalovo}

$8600 \pm 310$

Sphagnum (with Hypnum) peat, decomposition degree $10-15 \%$ sampling depth 2.40 to $2.45 \mathrm{~m}$. The supposed age is $8500 \mathrm{yr}$.

\section{Mo-323. Shuvalovo}

$8770 \pm 295$

6820 B.c.

Reed peat, decomposition degree $10-15 \%$, sampling depth 2.82 to $2.87 \mathrm{~m}$. The supposed age is 8500 to $9000 \mathrm{yr}$.

\section{Mo-324. Shuvalovo}

$8720 \pm 275$

6770 B.C.

Woody peat, well decomposed (to $50 \%$ ); sampling depth 3.13 to $3.18 \mathrm{~m}$. The supposed age is more than $9000 \mathrm{yr}$.

\section{Mo-325. Shuvalovo}

$4125 \pm 195$

A sawn piece of root from a border horizon (see Mo-320). Taken from a depth of 1.35 to $1.85 \mathrm{~m}$. The supposed age is 4000 to $5000 \mathrm{yr}$. 


\section{Osechenski Mokh Peat Bog series}

The Osechenski mokh deposit is situated in the Kalinin province near the town Vyshni Volochok (57 $30^{\prime} \mathrm{N}$ Lat, $34^{\circ} 50^{\prime} \mathrm{E}$ Long). The sampling was carried out from a slope, previously prepared by stripping back $1.25 \mathrm{~m}$ from the ditch border, to exclude the possibility of contamination. The general thickness of the peat deposit is $2.58 \mathrm{~m}$. Selections were carried out by M. I. Neistadt in 1962.

\section{Mo-326. Osechenski mokh}

$1605 \pm 170$

Sphagnum-cotton-grass peat, decomposition degree $10-15 \%$, sampling depth 0.75 to $0.80 \mathrm{~m}$. The supposed age is not over $2500 \mathrm{yr}$.

\section{Mo-327. Osechenski mokh}

$2885 \pm 185$

Cotton-grass-Sphagnum peat, decomposition degree $35 \%$, sampling depth 1.02 to $1.07 \mathrm{~m}$. The supposed age is not over $4500 \mathrm{yr}$.

\section{Mo-328. Osechenski mokh}

$3820 \pm 195$

Woody (pine) peat, decomposition degree $50-60 \%$. Sampling depth 1.20 to $1.27 \mathrm{~m}$, border horizon. The supposed age is not over $4500 \mathrm{yr}$.

Mo-329. Osechenski mokh

$6945 \pm 250$

4995 B.c.

Sphagnum-Carex peat with cotton grass, sampling depth 1.70 to $1.75 \mathrm{~m}$. The supposed age is not over $7700 \mathrm{yr}$.

\section{Mo-330. Osechenski mokh}

Peat (ryzhak, of Carex and reeds with wood remains), depth 2.25 to $2.30 \mathrm{~m}$. The supposed age is over $9800 \mathrm{yr}$.

\section{Mo-331. Osechenski mokh}

Woody peat, decomposition degree $50-60 \%$, depth 2.50 to $2.58 \mathrm{~m}$. The supposed age is about $9800 \mathrm{yr}$.

\section{Tiosovo-Netylskoye Peat Bog series}

The peat bog is located in the Novgorod province NW of Novgorod $\left(58^{\circ} 45^{\prime} \mathrm{N}\right.$ Lat, $31^{\circ} 00^{\prime} \mathrm{E}$ Long). The samples were taken from the ditch; the face of the ditch was cut back by $1.25 \mathrm{~m}$. The total section depth is $4.25 \mathrm{~m}$. Basal layer, $3.4 \mathrm{~m}$ to $4.25 \mathrm{~m}$, is light-olive-colored sapropel, becoming sandy downward. The samples were selected in 1962 by M. I. Neistadt and N. A. Khotinsky (Geog. Inst.) .

\section{Mo-347. Tiosovo-Netylskoye} $490 \pm 140$

Sphagnum fuscum peat; decomposition degree $5 \%$, sampling depth 0.25 to $0.30 \mathrm{~m}$. The supposed age is 300 to $500 \mathrm{yr}$. 
$1575 \pm 165$

Mo-348. Tiosovo-Netylskoye

A.D. 375

Sphagnum-cotton-grass peat, sampling depth 0.65 to $0.73 \mathrm{~m}$. The supposed age is 1000 to $1400 \mathrm{yr}$.

Mo-349. Tiosovo-Netylskoye

$2875 \pm 120$

925 B.c.

Woody Carex peat, greatly decomposed, bedding depth 1.05 to $1.10 \mathrm{~m}$. The supposed age is $3000 \mathrm{yr}$.

\section{Mo-350. Tiosovo-Netylskoye}

$3730 \pm 200$

1780 в.c.

Sphagnum-cotton-grass peat, of a lighter color, greatly decomposed, bedding depth 1.45 to $1.50 \mathrm{~m}$. The supposed age is 4000 to $4500 \mathrm{yr}$.

\section{Mo-351. Tiosovo-Netylskoye}

$6275 \pm 230$

4325 B.C.

Peat $(r y z h a k)$, rapidly darkening on exposure, with admixture of wood remains. Depth is 3.2 to $3.4 \mathrm{~m}$. The supposed age is about $7000 \mathrm{yr}$.

\section{Mo-346. Tiosovo-Netylskoye}

$5860 \pm 210$

3910 B.C.

Birch wood with bark remains, depth $2.33 \mathrm{~m}$. The supposed age is 5000 to $6000 \mathrm{yr}$.

\section{Berendeevo Peat Bog series}

The Berendeevo peat deposit is located near the railway station of the same name in the Yaroslav province, $100 \mathrm{~km} \mathrm{NE}$ of Moscow $\left(56^{\circ} 35^{\prime}\right.$ $\mathrm{N}$ Lat, $39^{\circ} 00^{\prime} \mathrm{E}$ Long). Its choice is explained by the fact that it is well known, having been exploited from 1906. A bore-hole was sunk in the NW part of the bog, in high moor peat, near the second pit. Total thickness of peat at boring site is $365 \mathrm{~cm}$; below is sapropel, $55 \mathrm{~cm}$ thick, overlying blue clay (Neistadt, Devirts, Markova, Dobkina, Khotinsky, 1962). The samples were selected by M. I. Neistadt in 1960 .

\section{Mo-206. Berendeevo}

$1020 \pm 150$

Sphagnum peat from a depth of $0.75 \mathrm{~m}$. Supposed age is upper part of Late Holocene (Sub-Atlantic period) ca. $1000 \mathrm{yr}$.

\section{Mo-207. Berendeevo}

$3360 \pm 150$

1410 B.c.

Sphagnum peat from a depth of $1.5 \mathrm{~m}$. Relative age is lower part of Late Holocene (Sub-Atlantic period). The approximate absolute age is ca. $2500 \mathrm{yr}$.

\section{Mo-208. Berendeevo}

$4730 \pm 190$ 2780 B.c.

Sphagnum-cotton-grass peat from a depth of $2.25 \mathrm{~m}$. Relative age is middle of Middle Holocene (Atlantic period). The approximate absolute age is ca. $5000 \mathrm{yr}$. 


\section{Mo-209. Berendeevo}

$5415 \pm 195$

3465 B.C.

Sphagnum-cotton-grass peat from a depth of $2.75 \mathrm{~m}$. Relative age is first half of Middle Holocene (Atlantic period), absolute age is ca. $6000 \mathrm{yr}$.

\section{Mo-210. Berendeevo}

$4220 \pm 180$

Carex (ryzhak) peat, sampling depth $3.25 \mathrm{~m}$. Relative age is beginning of Middle Holocene (Atlantic period). The supposed absolute age is ca. $7000 \mathrm{yr}$.

\section{Mo-211. Berendeevo}

$6090 \pm 210$

Sapropel, sampling depth $4.0 \mathrm{~m}$. Relative age is upper part of Early Holocene (Boreal period). The supposed absolute age is ca. $7500 \mathrm{yr}$.

\section{Mo-212. Berendeevo}

$4720 \pm 190$

Wood from the border horizon, depth of sampled layer 2.25 to $2.50 \mathrm{~m}$. The supposed age is ca. $5000 \mathrm{yr}$.

\section{Mo-213. Berendeevo}

$3630 \pm 165$

Root, cut from the border horizon at 2.25 to $2.50 \mathrm{~m}$ depth, at some distance from the chief section. The supposed age is ca. $5000 \mathrm{yr}$.

\section{Mo-214. Berendeevo}

$9160 \pm 280$

Wood from the same bog, but from another section, where the upper part of the deposit is already worked out. Sample was taken close to bottom of peat deposit. The supposed age is 9000 yr. Comment: the $\mathbf{C}^{14}$ determinations of peat from the main Berendeevo bog series (Mo206-211) give somewhat younger ages than were expected on the basis of the pollen analysis, though they are in stratigraphic order. An exception is Mo-210, the younger age of which is perhaps connected with contamination during drilling. The age of the wood Mo-212 closely approaches the age of peat at the same depth, $2.25 \mathrm{~m}$ (Mo-208). The woody layer sampled as Mo-213, which was found at the same depth, but at some distance, in a destroyed peatworks, gave a significantly younger age; perhaps it was the result of unequal settling, as bog had been drained.

\section{Lake Somino series}

The lake Somino is situated near the left bank of the Upper Volga, in the valley of its tributary, the river Nezl Volzhskaya (Pereslavlski district, Yaroslav province). It is surrounded by a whole group of bogs forming the Pereslavl-Usolsk peat massif $\left(56^{\circ} 50^{\prime} \mathrm{N}\right.$ Lat, $38^{\circ} 30^{\prime} \mathrm{E}$ Long) . The total thickness of the deposit is $40.0 \mathrm{~m}$. Samples from two holes 
(No. 10 and No. 86), located in the SE part of the lake at a distance of $0.5 \mathrm{~km}$ from one another, were investigated to establish the absolute chronology of the oldest Holocene sections (Vinogradov, Devirts, Markova, Khotinsky, 1963). The samples were selected by N. A. Khotinsky (Geog. Inst., Acad. of Sci., USSR).

\section{Mo-259. Somino}

Black fine-detritus gyttja from lower part of lacustrine strata, $40 \mathrm{~m}$ thick, of lake Somino. Sample from hole No. 10 at a depth of 36.2 to $37.0 \mathrm{~m}$. The supposed age is 9000 to $10,000 \mathrm{yr}$.

Mo-262. Somino

$9780 \pm 315$ 7830 B.c.

Fine-detritus gyttja from same hole as Mo-259, but from depth of 38.0 to $38.5 \mathrm{~m}$. The supposed age is 9000 to $10,000 \mathrm{yr}$.

\section{Mo-264. Somino}

Fine-detritus gyttja from same hole as Mo-259, but from depth of 39.0 to $39.5 \mathrm{~m}$. The supposed age is 9000 to $10,000 \mathrm{yr}$.

\section{Mo-266. Somino}

$9430 \pm 300$

Buried sapropel from layer laid bare by hole No. 86. Here, under sands, at 17 to $22 \mathrm{~m}$ depth, sapropel is $5 \mathrm{~m}$ thick. Sampling depth is 17.05 to $17.45 \mathrm{~m}$. Spores and pollen, isolated from the lake sediments, show that the vegetative cover developed under rigorous climatic conditions. Before dating, it was supposed that the sapropel accumulation occurred at the end of the Valdai glaciation.

\section{Mo-268. Somino}

$10,260 \pm 330$

Gray mineralized sapropel from same hole as Mo-266, sampling depth 18.5 to $19.5 \mathrm{~m}$. The supposed age is the boundary between lateglacial and postglacial time.

\section{Mo-271. Somino}

$10,535 \pm 330$

8585 B.c.

Gray mineralized sapropel from same hole as Mo-266, sampling depth 21.0 to $22.0 \mathrm{~m}$. Pollen analysis shows predominance of grass and shrub formations, which agrees with the ideas about the forestless landscapes of the Upper Dryas.

\section{Melekhovo Peat Bog series}

The bog is located in the Pereslavl district of the Yaroslav province, at $\mathrm{S}$ border of the Polovets-Kupansk peat deposit, $15 \mathrm{~km} \mathrm{~N}$ of lake Somino ( $56^{\circ} 55^{\prime} \mathrm{N}$ Lat, $38^{\circ} 35^{\prime} \mathrm{E}$ Long). Samples for pollen and spore analysis were selected from this bog in 1961. Having at his disposal a detailed diagram, N. A. Khotinsky selected in 1963 at the same point 
samples for radiocarbon analysis, taking into account the most important stratigraphical levels of the Holocene deposits. The two sapropel samples dated here are intended to give a more precise notion of age of the boundary between the late-glacial and postglacial time. The total thickness of the deposit is $12 \mathrm{~m}$ (Khotinsky, $1964 \mathrm{a}, \mathrm{b}$ ).

\section{Mo-361. Melekhovo}

$11,370 \pm 370$

Light-grey sapropel; contact with underlying black gyttja is very distinct. Sampling depth 10.25 to $10.40 \mathrm{~m}$. The supposed age corresponds to the Upper Dryas, 10,300 to 10,900 B.P.

\section{Mo-360. Melekhovo}

$11,975 \pm 300$

Sapropel of a dark-grey, almost black color, sampling depth 10.6 to $10.75 \mathrm{~m}$. The supposed age corresponds to the Alleröd and is estimated as 11,000 to $12,000 \mathrm{yr}$.

General Comment: study of $\mathrm{C}^{14}$ results on peat deposits, together with stratigraphic data, provides details in the Holocene subdivision which existed before on the basis of paleobotanic data (Neistadt, 1957); it gives dates of biostratigraphic levels or boundaries that correspond to considerable changes of the vegetative cover over enormous territories, and traces the duration of some Holocene periods.

The dated levels facilitate synchronization of Holocene events on the territory of the Russian plain with those of Western Europe. Thus, according to the peats of the lake Somino (Mo-268), the transition from the late-glacial to the postglacial period took place on the Russian plain $10,260 \mathrm{yr}$ ago. This event is synchronous with that in Western Europe, where deposits in Denmark, England and Sweden showed the absolute figure of 10,300 yr (Iversen, 1953; Godwin, Walker, Willis, 1957; Nilsson, 1964). Older peat deposits, dating from the late-glacial period, had not been found before on the territory of the Russian plain. Now, according to samples from the Melekhovo peat deposit (Mo-360, Mo-361) we have layers corresponding to the Alleröd and the Upper Dryas, and these important stratigraphic boundaries are also correlated with Western Europe.

The establishment of a border (recurrence) horizon in the peats under investigation, marked by buried wood and stumps, is dated in the range from 7000 or 6000 to 3000 B.P. (Mo-321, Mo-319, Mo-328, Mo-207). The border horizon was apparently produced by a drier and warmer climate, when a forest vegetation began to grow on the bogs.

\section{Imnatskoye Peat Bog series}

The Imnatskoye peat deposit is a part of the vast Potian bog, located 8-9 km SW of Poti in the Georgian Soviet Socialist Republic $\left(42^{\circ} 00^{\prime} \mathrm{N}\right.$ Lat, $41^{\circ} 45^{\prime} \mathrm{E}$ Long.). It was chosen by reason of the considerable thickness of the peat bed, ca. $11.3 \mathrm{~m}$, known from preliminary 
data to have begun deposition 9000 to 10,000 yr ago. A confirmation of these data would provide an absolute chronological scale for the whole Holocene. The peat samples were coll. by N. A. Khotinsky in 1961 by Hiller auger in a central area of high moor type.

Mo-249. Imnatskoye

Peat, sampling depth 1.75 to $2.00 \mathrm{~m}$. Supposed age is 1000 to $1500 \mathrm{yr}$.

\section{Mo-251. Imnatskoye}

$2100 \pm 150$

Peat, sampling depth 5.75 to $6.0 \mathrm{~m}$. Supposed age is 4000 to $5000 \mathrm{yr}$.

$\begin{aligned} & 4130 \pm 195 \\ & \mathbf{2 1 8 0} \text { B.C. }\end{aligned}$

\section{Mo-253. Imnatskoye}

2180 B.C.

Peat, sampling depth 8.25 to $8.50 \mathrm{~m}$. Supposed age is 8500 to $9000 \mathrm{yr}$.

\section{Mo-254. Imnatskoye}

$5825 \pm 215$

3875 B.c.

Peat, sampling depth 11.0 to $11.3 \mathrm{~m}$. Supposed age is 9500 to 10,000 yr. Comment: the dating has shown that the 11-m-thick peat bed began to form ca. 6000 years ago, i.e., that it is considerably younger than was assumed. In this connection it is of interest to make use of data obtained in investigating bottom sediments of the Black Sea. Thus, marine sediments taken off nearby Batumi (see below, Mo-283, 344) belong to older phases of the Holocene and even to the Upper Pleistocene and may be considered as a continuation of the Imnatskoye section.

\section{B. Samples connected with the glaciation and formation of post-glacial landscapes}

In the first part of this section are collected samples connected with the study of events during and after the last glacial age in the NW European part of the USSR: time fixation of the end of the last Valdai glaciation on the Russian plain, definition of the number and duration of glacial stages and interstadials, elucidation of the rate of glacier retreat, the time of low river-terrace formation, and other problems. Although the Valdai glaciation (correlative with the Würm glaciation in Western Europe) is the nearest to our time, its stratigraphy is the most intricate. Until now a number of scientists (A. I. Moskvitin, V. P. Grichuk) have divided the time after the Mikulinski interglacial age into 2 independent glaciations, between which was the Mologo-Sheksninskoye interglacial age. This problem has been considered in examining a number of samples from lake and bog deposits, both within the glaciated territory and beyond its borders.

\section{Baltic Regions}

$13,390 \pm 500$

\section{Mo-296. River Rauna, Ratseni (Latvia)}

11,440 B.c.

Plant remains contained in aleurite with sand, coll. from a section at the r. Rauna close to the farm Ratseni, Latvian SSR $\left(57^{\circ} 10^{\prime} \mathrm{N}\right.$ Lat, 
$24^{\circ} 50^{\prime} \mathrm{E}$ Long). In this section a thick moraine layer crops out, on which are superposed lacustrine deposits overlapped by a thin bed of red-brown loam and aleurites. The lacustrine deposits contain remains of a polar vegetation (polar birch, willow, Dryas octopetala, etc.). Sample was taken from this layer at a depth of ca. $3 \mathrm{~m}$ from the surface. To judge by the vegetation character, the accumulation of lacustrine deposits occurred under conditions of a cold climate-in the Late-glacial period. Coll. 1962 by I. Ya. Danilans (Acad. of Sci. of the Latvian SSR) and N. S. Chebotareva (Geog. Inst., Acad. of Sci., USSR).

\section{Mo-317. River Letizhe, Desele (Latvia)}

Peat between tills from a river-bank section (Danilans, 1962) in the lower reaches of the river Letizhe (tributary of the $r$. Venta) near the settlement Desele in the Latvian SSR ( $56^{\circ} 20^{\prime} \mathrm{N}$ Lat, $22^{\circ} 00^{\prime} \mathrm{E}$ Long). Between two moraine layers there is a lacustrine-to-boggy deposit represented in the lower part by sandy bluish clay overlying red till. Over the clay is organic mud containing well-preserved, strongly mineralized plant remains, overlain by dark-brown compact peat, 0.1 to $0.33 \mathrm{~m}$ thick; sample was taken from this peat layer. A gray clay, $0.2 \mathrm{~m}$ thick, overlies the peat and is overlain by alternating sand and brown clay, then by light-yellow laminated sand, $0.8 \mathrm{~m}$ thick, and finally, with gradational contact, by red till, the thickness of which in the section is ca. $3 \mathrm{~m}$. The data of pollen analysis are vague and show only that the accumulation of lacustrine-to-boggy sediments occurred during some interstadial. Coll. 1962 by I. Ya. Danilans and N. S. Chebotareva.

\section{Mo-318. River Gauya, Leyastiems (Latvia)}

Peaty gyttja from a section on the left bank of the $r$. Gauya near the settlement Leyastiems in the Latvian SSR $\left(57^{\circ} 30^{\prime} \mathrm{N}\right.$ Lat, $26^{\circ} 40^{\prime} \mathrm{E}$ Long). The lacustrine deposits are sands and gray aleurites, saturated with organic remains (pieces of moss, grass), and are crumpled and partly included in the red-brown moraine $6 \mathrm{~m}$ thick that overlies them (Danilans, 1962). According to pollen analysis climatic conditions during the accumulation of lacustrine sediments were rather temperate; apparently they belong to an interstadial of the Valdai glaciation. Coll. 1962 by I. Ya. Danilans and N. S. Chebotareva.

\section{Mo-35. River Neman, Lipliunai (Lithuania) A.D. 1000}

Wood from hanging peat bog exposed in terrace, 12 to $13 \mathrm{~m}$ high, on left bank of $r$. Neman, near the village Lipliunai, $5 \mathrm{~km}$ above the town Druskininkai in the Lithuanian SSR $\left(54^{\circ} 00^{\prime} \mathrm{N}\right.$ Lat, $24^{\circ} 00^{\prime} \mathrm{E}$ Long). Bog deposit is exposed in section between $7.0 \mathrm{~m}$ and 2.5 to $3.0 \mathrm{~m}$ above river level. It was formed during a period of a higher level of ground water, marked also by formation of a flood plain ca. $3 \mathrm{~m}$ high, in late Sub-Boreal or Sub-Atlantic time; it is not older than 3000 to $2000 \mathrm{yr}$ and perhaps still younger. Sample was coll. 1956 from the middle 
of the peat layer by L. N. Voznyachuk (Geol. Inst. of the Acad. of Sci. of the Belorussian Soviet Socialist Republic).

Mo-36. R. Neman, Lipliunai (Lithuania)

Recent

Wood from the same outcrop as Mo-35. The sample was taken from the outer side of the peat bog. It is not clear whether the wood is of the same age as the peat bog.

\section{Mo-46. Purmaliai (Lithuania)}

$6100 \pm 230$

$6000 \pm 240$

Peat with wood from an outcrop near the settlement Purmaliai, Klaipeda district, Lithuanian SSR (55 $45^{\prime} \mathrm{N}$ Lat, $21^{\circ} 20^{\prime} \mathrm{E}$ Long). The sample was taken from a bed, 0.4 to $0.6 \mathrm{~m}$ thick, at a depth of $15 \mathrm{~cm}$. Subm. by V. K. Gudelis (Geol. and Geog. Inst. of the Acad. of Sci., Lithuanian SSR). Comment: the first figure is obtained by measuring ethane, the second by measuring $\mathrm{CO}_{2}$.

Mo-202. Purmaliai (Lithuania) $>29,000$

Peat, settlement Purmaliai, Klaipeda district, Lithuanian SSR $\left(55^{\circ}\right.$ $45^{\prime} \mathrm{N}$ Lat, $21^{\circ} 20^{\prime} \mathrm{E}$ Long). Stratigraphy: peat is located at a depth of ca. $20 \mathrm{~m}$ overlain by sand, ca. $4 \mathrm{~m}$ thick, with an admixture of organic matter, then by till, $6 \mathrm{~m}$ thick. Peat is also underlain by sand with an admixture of organic matter. The supposed age is the interstadial of the last glaciation. Coll. 1960 and subm. by V. K. Gudelis (Gudelis, 1961) .

\section{Mo-203. Lake Berzuolaitis (Lithuania)}

$8580 \pm 270$

Peat from a bog of the lake Berzuolaitis, $15 \mathrm{~km} \mathrm{SW}$ of Vievis, Lithuanian SSR (54 $40^{\prime} \mathrm{N}$ Lat, $24^{\circ} 40^{\prime} \mathrm{E}$ Long). The bog is located in a glacigenous rill on the tract of the terminal moraines. Peat, sapropelized, occurs at a depth of 8 to $9 \mathrm{~m}$, overlain by a lime-rich sapropel. The supposed age is Alleröd or Late Dryas or even the beginning of the Early Holocene. Coll. 1960 by A. A. Seibutis (Geol. and Geog. Inst. of the Acad. of Sci., Lithuanian SSR).

\section{Mo-204. Vievis (Lithuania)}

$9860 \pm 300$

7910 B.C.

Peat from a bog within the city limits of Vievis, Lithuanian SSR ( $54^{\circ} 50^{\prime} \mathrm{N}$ Lat, $24^{\circ} 50^{\prime} \mathrm{E}$ Long). Sapropelized peat, the upper layer of which underlies sapropel, occurred at $6.55 \mathrm{~m}$ depth, in a district of monticulate (morainic) relief. The supposed age is the end of Late Dryas, beginning of the Early Holocene. Coll. 1960 by A. A. Seibutis (Seibutis, 1962).

\section{Mo-205. Vievis (Lithuania)}

$11,200 \pm 340$

9250 B.c.

Peat from the same bog as Mo-204. Lower sapropelized peat layer at a depth of $7.0 \mathrm{~m}$. The supposed age is the second half of the Alleröd period. Coll. 1960 by A. A. Seibutis. 


\section{Mo-302. River Ula, Zervynos (Lithuania)}

$16,260 \pm 640$

Moss from a section, laid bare by the $r$. Ula (tributary of the $r$. Merkys) near the village Zervynos, district of the town Varena, Lithuanian SSR (54 $05^{\prime} \mathrm{N}$ Lat, $24^{\circ} 30^{\prime} \mathrm{E}$ Long). The $\mathrm{r}$. Ula cuts the frontal apron, located along the outer margin of the Baltic ridge, that formed during the Pomeranian stage of the Valdai glaciation; below occur interstadial lacustrine-bog deposits, as well as sands of the Brandenburg stage. The lacustrine-bog deposits, consisting of clays and aleurites, form a lens interbedded between the sands. At their base at a depth of over $2 \mathrm{~m}$ from the surface occurs a well-preserved layer of green moss, $0.05 \mathrm{~m}$ thick, from which the material for analysis was taken by stripping to a depth of $0.75 \mathrm{~m}$. On basis of pollen analysis Lithuanian scientists assign the lacustrine-bog stratum to an interstadial between the Pomeranian and the Brandenburg stages (Kondratiene, 1950; Basalikas, 1957). Coll. 1962 by N. S. Chebotareva and O. P. Kondratiene (Acad. of Sci. of the Lithuanian SSR).

\section{Mo-339. River Ula, Rudnia (Lithuania)}

$12,715 \pm 315$ 10,765 в.c.

Peat from a section, laid bare by the $r$. Ula (tributary of the $r$. Merkys) near the village Rudnia, up-river from the village Zervynos (see Mo-302), Lithuanian SSR (54 $05^{\prime} \mathrm{N}$ Lat, $24^{\circ} 40^{\prime}$ E Long). Section exposes structure of an outwash plain striking SE from the Baltic ridge. Peat lens occurs under sand layer, 7 to $8 \mathrm{~m}$ thick. Paleobotanic investigations have shown that during the peat accumulation the climate was very temperate; plant cover was chiefly pine and birch. It is supposed that this episode corresponds to the interstadial preceding the Pomeranian stage of the Valdai glaciation. Sample coll. 1962 by O. P. Kondratiene.

\section{Mo-341. River Merkys, Pamerkes (Lithuania)}

$11,500 \pm 400$

9550 в.c.

Peat from a section, laid bare by the $r$. Merkys near the village Pamerkes in the district of the town Varena, Lithuanian SSR $\left(54^{\circ} 20^{\prime}\right.$ $\mathrm{N}$ Lat, $24^{\circ} 45^{\prime} \mathrm{E}$ Long). Section exposes structure of an outwash plain striking SE from the Baltic ridge. A lacustrine-boggy lens with two peat horizons is included in a stratum of sand. Sample was taken from the upper horizon at a depth of $4.5 \mathrm{~m}$ from the surface. According to pollen analysis the accumulation of the whole lacustrine-boggy stratum occurred during the interstadial preceding the Pomeranian stage of the last glaciation. Sample coll. 1962 by O. P. Kondratiene.

\section{0,310 в.c.}

Wood and peat from the lower horizon of the same lacustrine-boggy stratum as Mo-341. The sampling depth is $6.5 \mathrm{~m}$ from the surface. 


\section{Mo-34. River Neman, Gozha}

$8500 \pm 300$

6550 в.c.

Wood, right side of the $\mathrm{r}$. Neman, village Gozha, below the town Grodno (53 $50^{\prime} \mathrm{N}$ Lat, $23^{\circ} 50^{\prime} \mathrm{E}$ Long). Sample was selected from a lenticular mort-lake formation, lying in a deep cut in the base of alluvium underlying the second, 10 to $15 \mathrm{~m}$ terrace. According pollen geomorphic observations the alluvium of the second terrace of the Neman dates from the end of the Pre-Boreal and the first half of the Boreal periods, 9500 to 8500 yr ago. Coll. 1956 by L. N. Voznyachuk (Geol. Inst. of the Acad. of Sci. of the Byelorussian SSR) (Voznyachuk, 1959).

Mo-299. Zaberdovo

$>\mathbf{2 8 , 0 0 0}$

Wood from a brickworks pit near the village Zaberdovo, Korelich district, Grodno province ( $53^{\circ} 30^{\prime} \mathrm{N}$ Lat, $25^{\circ} 55^{\prime} \mathrm{E}$ Long). Zaberdovo is located on a hill (Novogrudskaya) beyond the boundaries of the Valdai glaciation. Lacustrine-boggy deposits occur here in a depression in the surface of the older (Moscow glaciation) moraine and of the glaciolacustrine clays that lie on it. They consist of peat, clays, and aleurite. A great amount of wood is included in the peat. A sample was taken at a depth of ca. $1 \mathrm{~m}$ from the surface. Over the peat only aleurites are lying; there are no glacial deposits. To judge by the stratigraphic conditions, the peat could have accumulated either during the Mikulinsk interglacial period or during an interstadial of the last glaciation, or even in the Holocene. Spores and pollen suggest that the peat was deposited under a rather cold climate, but such a climate is known from various periods of the Pleistocene and Holocene. Sample coll. 1962 by N. S. Chebotareva.

\section{Center of the European Part of USSR}

\section{Mo-201. Gorelovo}

$12,150 \pm 390$

10,200 в.C.

Pine wood from a peat-bog near the $r$. Dudergovka, near the station Gorelovo, $15 \mathrm{~km}$ SW of Leningrad $\left(59^{\circ} 50^{\prime} \mathrm{N}\right.$ Lat, $30^{\circ} 10^{\prime} \mathrm{E}$ Long). The sample was taken at a depth of $1.2 \mathrm{~m}$ from the surface. The peat bog is overlapped by transgressive deposits of a young stage of the Baltic glacial lake. Here and there the peat passes into fossil gley soil. The peat flora is non-arctic, with much birch bark and pine wood. The sands overlapping the peat were formed as an offshore bar at ca. $30 \mathrm{~m}$ alt above present sealevel, an altitude that reaches the isobase drawn on the surface of the last stage of the Baltic glacial lake which is synchronous with the Salpausselkä moraines. From this it follows that the relative age of the peat bog is Late Gacial (Older Holocene). As far back as $1931 \mathrm{~K}$. K. Markov, according to varved clays and data of pollen analysis, has estimated the age of this peat as Alleröd. The sample was coll. 1960 by $O$. M. Znamenskaya (Leningrad State Univ.) and subm. by K. K. Markov 
(Moscow State Univ.). The sample has been described (Serebryanny, Devirts, Markova, 1962).

\section{Mo-257. River Kynya, Spas-Priluki}

Peat, river bank of the $r$. Kynya near the village Spas-Priluki of the Ploskosh district in the Pskov province $\left(56^{\circ} 50^{\prime} \mathrm{N}\right.$ Lat, $31^{\circ} 00^{\prime} \mathrm{E}$ Long). The sampling depth is 9.9 to $10.0 \mathrm{~m}$ from the top of stripping, $10 \mathrm{~cm}$ above the water line of the $r$. Kynya. The stripping has laid bare (from the top downwards): moraine; sandy loam with gravel and pebbles; glaciolacustrine clays; horizontally stratified lacustrine sands with plant remains; foliated peat; coarse sand. The supposed age is the interstadial preceding the Krestetsk stage or older, i.e., from 55 to 30 or 25 thousand years. There are data of spore and pollen analysis which establish the interstadial character of the deposits. The sample was selected in 1960 by N. A. Korina (Geog. Inst. Acad. Sci., USSR).

\section{Mo-242. River Balazna, Boyarshchina}

$5120 \pm 200$

3170 B.C.

Plant remains from clays of the 5-to-6-meter terrace of the r. Balazna where it discharges into the r. Kasplyu (basin of the Western Dvina) near the village Boyarshchina, Smolensk province $\left(55^{\circ} 15^{\prime} \mathrm{N}\right.$ Lat, $31^{\circ}$ $20^{\prime} \mathrm{E}$ Long). Sample was taken at a depth of $2 \mathrm{~m}$ below top of terrace. The outcrop is $150 \mathrm{~m}$ above the mouth of the $\mathrm{r}$. Balazna on its left side, where the terrace is not as high above the river as elsewhere; this is the location of a mort-lake depression that is well marked in the local relief. The section exposes a mort-lake lens built of clays which alternate with sands in the lower part. The clays contain a great amount of plant remains. The pollen analysis did not give a distinct picture, therefore the supposed age could be Holocene or 25 to 30 thousand yr. Coll. 1961 by N. S. Chebotareva (Gerasimov, Serebryanny, Chebotareva, 1963; Serebryanny, Chebotareva, 1963).

\section{Mo-243. River Kunya, Sukhaya Gorka}

$6675 \pm 235$

4725 в.c.

Wood from alluvial deposits of the first terrace of the $\mathrm{r}$. Kunya near the village Sukhaya Gorka, Toropetsk district, Kalinin province $\left(56^{\circ}\right.$ $40^{\prime} \mathrm{N}$ Lat, $31^{\circ} 00^{\prime} \mathrm{E}$ Long). The sample was taken by stripping, at a depth of 2.15 to $2.20 \mathrm{~m}$. The stripping lays bare the structure of the terrace: sandy deposits of a mort-lake lens containing plant remains, overlain by floodplain sandy loam, overlying coarse sand of the river-bed facies. The supposed age is either 25 to 35 thousand yr or Holocene. Coll. 1900 by N. A. Korina and M. A. Faustova (Geog. Inst. Acad. of Sci., USSR).

\section{Mo-244. R. Kunya, Sukhaya Gorka}

$7120 \pm 245$

5170 B.c.

Wood from the same section as Mo-243, but from a depth of 2.75 to $2.80 \mathrm{~m}$. 


\section{Mo-293. River Shcheberikha, Rvenitsy}

Wood from section of terrace of the $\mathrm{r}$. Shcheberikha, $7 \mathrm{~m}$ high, near the village Rvenitsky, Kalinin province ( $57^{\circ} 30^{\prime} \mathrm{N}$ Lat, $32^{\circ} 40^{\prime} \mathrm{E}$ Long). Section is located within the limits of the Valdai glaciation. In the studied section of the terrace mort-lake deposits are found to contain plant remains and wood. The mort-lake deposits overlie a moraine which is the latest for this terrace-the highest in the valley of the $r$. Shcheberikha. The moraine is covered by alluvium. The sample was taken from a depth over $3.5 \mathrm{~m}$. The supposed age of the deposits is Holocene. According to pollen analysis the accumulation of mort-lake sediments must have taken place in a relatively warm period, obviously warmer than the recent one. Coll. 1962 by N. S. Chebotareva.

\section{Mo-237. River Melecha, Borok}

$8580 \pm 150$

Peat from alluvial deposits of a high flood plain of the $r$. Melecha near the village Borok, $\mathrm{N}$ of the town Bezhetsk, Kalinin province $\left(58^{\circ}\right.$ $10^{\prime} \mathrm{N}$ Lat, $36^{\circ} 40^{\prime} \mathrm{E}$ Long). The sampling depth is 2.2 to $2.4 \mathrm{~m}$. Besides the high flood plain there are no indications of alluviation at higher levels-neither higher terraces nor sloping benches. The river banks, veneered at the surface by light-brown aleurites (overlying moraine), typically have very gentle slopes. The flood plain lies 3.65 to $4.0 \mathrm{~m}$ above the river level, and is known to be overflowable. In some places near Borok are outcrops which expose this terrace structure. From the surface are aleurites which gradually pass into fine gray clay with a great amount of plant remains in the lower part; below is peat $(0.1$ to $0.3 \mathrm{~m}$ thick), overlying gray clay. The section near Borok has long been known in the literature (from 1909): it was thought that these deposits are overlapped by a moraine and had accumulated in the Mikulinsk interglacial period, i.e., that the peat age would be $>60,000$ B.P. In the opinion of N. S. Chebotareva, who coll. this sample in 1960, considering the fact that deposits belong to the flood plain, the age is Holocene. According to palynologic data the layers enclosing the sample accumulated in the beginning of the climatic optimum of the Holocene.

\section{Mo-238. Toporikha \\ $>\mathbf{3 3 , 0 0 0}$}

Wood, taken on the watershed near the $\mathrm{E}$ border of the village Toporikha in a trench, made during excavation of a pond, Kalinin province $\left(57^{\circ} 25^{\prime} \mathrm{N} \mathrm{Lat}, 36^{\circ} 30^{\prime} \mathrm{E}\right.$ Long). Here (from top to bottom) were exposed fine sand, aleurites, gray clay with plant remains, peat with much wood; under the peat aleurites again occur, passing below into sand. Layers below the peat were explored by boring. The general thickness of the stripped deposits is $4.1 \mathrm{~m}$; the sample was taken from a depth of 2 to $2.5 \mathrm{~m}$. Pollen analysis did not give a distinct picture. The supposed age is 10,000 to 65,000 yr. Coll. 1960 by N. S. Chebotareva. 


\section{Mo-198. River Bolshaya Lipnya, Barmino}

Wood imbedded in the first terrace of the r. B. Lipnya near the village Barmino $(60 \mathrm{~km} \mathrm{~W}$ of the town Vladimir), Vladimir province $\left(56^{\circ} 00^{\prime} \mathrm{N}\right.$ Lat, $39^{\circ} 40^{\prime} \mathrm{E}$ Long). Character of the deposit: an accumulation of tree trunks, plant remains, cones, etc., occur in the form of a lens in the strata of the first terrace. Sample was coll. during stripping of the river cliff at a depth of $2.3 \mathrm{~m}$ below the surface of terrace, which is $4 \mathrm{~m}$ high. Sample is somewhat younger than Mo-199. According to micropaleobotanic investigations of the section, there are reasons to consider the deposits as belonging to an interglacial period younger than the Riss-Würm (the Mikulinsk). Coll. 1960 by V. P. Grichuk and L. R. Serebryanny (Geog. Inst. Acad. Sci., USSR).

\section{Mo-199. River B. Lipnya, Barmino}

Wood from the same terrace as Mo-198, but taken at a depth of 3.4 $\mathrm{m}$ below surface.

\section{Mo-200. River Klyasma, Voinova Gora \\ $945 \pm 95$ \\ Wood from deposits of the first terrace of the r. Klyasma, near the} village Voinova Gora in the vicinity of the Orekhovo Zuyevo, Vladimir province $\left(55^{\circ} 50^{\prime} \mathrm{N}\right.$ Lat, $39^{\circ} 10^{\prime} \mathrm{E}$ Long). An accumulation of tree trunks, plant remains, etc., is imbedded in this terrace in the form of a lens. Sample was taken in stripping a river cliff at ca. $3 \mathrm{~m}$ depth. On paleobotanic evidence from the section, the deposits may date from an interglacial age, younger than the Mikulinsk interglacial (Riss-Würm). Coll. 1960 by V. P. Grichuk and L. R. Serebryanny (Gerasimov, Serebryanny, Chebotareva, 1963).

General Comment: in considering the sample ages of this group and comparing them with the characteristics of the sampling places some general conclusions are outlined. Until now no samples of organic origin have been found in the range of 17,000 to 34,000 B.P. (in these investigations $34,000 \mathrm{yr}$ was the age limit). Lacking such samples, there is as yet no warrant for recognizing the younger (Mologo-Shekninsk) interglacial age. All samples selected with the aim of demonstrating this debatable interval, of a supposed age of 25,000 to $30,000 \mathrm{yr}$, proved to belong to the Holocene (Mo-198, Mo-199, Mo-200, Mo-237, etc.). Other dates show that the glaciers retreated from the south of Lithuania as far north as Leningrad in the time interval from 16,000 to 12,000 B.P.; consequently the process of ice wastage on this territory lasted ca. $4000 \mathrm{yr}$ (Mo-201, Mo-296, Mo-302; Gerasimov and Chebotareva, 1963). The duration of the Alleröd interstadial is approx. $1000 \mathrm{yr}$ and embraces the time from 12,000 to $11,000 \mathrm{yr}$ ago (Mo-201 and Mo-205). The formation of low river terraces in the center of the Russian plain, both in the glaciated territory and beyond its borders, occurred in the Holocene (Mo- 
237, Mo-242, etc.; Chebotareva, Serebryanny, Devirts, and Dobkina, 1962;

Chebotareva and Serebryanny, 1963).

\section{River Desna Fossil Soils series}

Fossil soils from the periglacial zone of the Valdai glaciation are special indicators of paleoclimates and may serve for glacial-stratigraphic control as they show the influence of glaciation in their formation. In the present work samples of buried soils were taken from two sections, $250 \mathrm{~km}$ distant from one another. In these sections are 2 or 3 buried soils, of which the lower belong to the Mikulinsk interglacial period. We have analyzed the middle horizons in both sections. The carbon content in such samples is very low (a few percent) and therefore large amounts of soil (5 to $10 \mathrm{~kg}$ ) had to be processed for dating. Samples were coll. 1962 by T. D. Morozova and A. A. Velichko (Georg. Inst. Acad. Sci., USSR).

\section{Mo-337. River Desna, Bryansk}

$24,920 \pm 1800$ 22,970 в.c.

Fossil soil from the plateau on the right side of the $r$. Desna near the southern vicinity of the town Bryansk, Bryansk province $\left(53^{\circ} 15^{\prime} \mathrm{N}\right.$ Lat, $34^{\circ} 30^{\prime} \mathrm{E}$ Long). The sample was taken from the ravine wall at a depth of $4.25 \mathrm{~m}$ from the surface; it is a humic horizon of a soil formed in loesses of the Valdai sequence. All humic substances were completely isolated from the soil to analyze them for $\mathrm{C}^{14}$. According to geological data the supposed age is the interstadial of the Valdai glacial stage.

\section{Mo-342. River Desna, Mezin}

$24,200 \pm 1680$

Fossil soil from the right side of the $r$. Desna near the village Mezin, Chernigov province $\left(51^{\circ} 30^{\prime} \mathrm{N}\right.$ Lat, $33^{\circ} 00^{\prime} \mathrm{E}$ Long). The sample was taken from the ravine wall at depth of $8.7 \mathrm{~m}$ from the surface. Sample was the humic horizon of a soil formed in loesses of the Valdai sequence. The sample preparation for $\mathrm{C}^{14}$ analysis was the same as for Mo-337. The supposed age is the interstadial of the Valdai glacial stage.

Comment: fossil soils from the middle horizons in both sections proved to be of the same age, ca. 25,000 B.P. The dates provide means of correlating the last (Valdai) glaciation on the Russian plain with the Paudorf interstadial of the West-European glaciation (Velichko, Devirts, Dobkina, Morozova, Chichogova, 1964).

\section{Eastern Siberia}

Beyond the Russian plain the problems connected with glacial and postglacial deposits were studied on the territory of Eastern Siberia. In the present paper samples from two regions of Eastern Siberia (Yakutia) are cited: from the basins of the rivers Vilyui (tributary of the r. Lena) and Indigirka. 


\section{Vilyui River Basin series (Yakutia)}

Samples from the outcrops of the r. Vilyui were coll. by M. N. Alekseev in 1953 (Geol. Inst. of the Acad. of Sci., USSR) and A. V. Trofimov (V. I. Vernadsky Inst. of Geochemistry) and by M. N. Alekseev in 1955 (Alekseev, 1957).

Mo-136. River Vilyui

Recent

Wood, left side of the $\mathrm{r}$. Vilyui, $1 \mathrm{~km}$ below the river Byrykan mouth $\left(63^{\circ} 50^{\prime} \mathrm{N}\right.$ Lat, $122^{\circ} 40^{\prime} \mathrm{E}$ Long). The sample was taken at a depth of $1 \mathrm{~m}$ from the surface from deposits of a high flood-plain, formed in part during the thermal optimum in the Holocene. The supposed age is 2000 to $10,000 \mathrm{yr}$.

\section{Mo-137. River Vilyui}

$1910 \pm 120$

Wood from the same outcrop as Mo-136, but from a depth of $25 \mathrm{~m}$. The supposed age is 2000 to $10,000 \mathrm{yr}$.

\section{Mo-138. River Vilyui}

Wood, left side of the $\mathrm{r}$. Vilyui, $5 \mathrm{~km}$ above the landing Lankholokh. The supposed age is 12 to 30 thousand yr.

\section{Mo-139. River Vilyui}

Wood from a humified horizon, left side of the r. Vilyui, $4 \mathrm{~km} \mathrm{NW}$ of mouth of the $\mathrm{r}$. Tangnary $\left(64^{\circ} 05^{\prime} \mathrm{N}\right.$ Lat, $124^{\circ} 00^{\prime} \mathrm{E}$ Long). The supposed age is 12 to 30 thousand yr.

\section{Mo-140. River Vilyui}

Wood and peat from sandy loams, left side of the $\mathrm{r}$. Vilyui, $5 \mathrm{~km} \mathrm{~N}$ of mouth of the $\mathrm{r}$. Tangnary $\left(64^{\circ} 05^{\prime} \mathrm{N}\right.$ Lat, $124^{\circ} 00^{\prime} \mathrm{E}$ Long). Sampling depth is ca. $10 \mathrm{~m}$. The supposed age is approx. the end of $Q_{3}$. The nature of the sediment indicates an intensification of the continental character of the climate.

\section{Mo-141. River Vilyui}

Peat from lacustrine sand-loams, crumpled by cryoturbation, left side of the r. Vilyui, $13 \mathrm{~km}$ below the mouth of the $\mathrm{r}$. Chebydy $\left(63^{\circ} 50^{\prime}\right.$ $\mathrm{N}$ Lat, $120^{\circ} 50^{\prime} \mathrm{E}$ Long). Sample was taken from a depth of ca. $10 \mathrm{~m}$. The supposed age is the end of the Upper Pleistocene, approx. corresponding to the Sartansk (last) stage of the Zyryansk glaciation of Siberia. Comment: datings of the samples from the basin of the r. Vilyui (Yakutia) were obtained during the first working stage of the laboratory, when there was no experience in sampling for radiocarbon analysis. Though most of the datings proved older than expected, nevertheless they are of certain interest, as there are very few data on absolute geological ages for Siberia. 


\section{Indigirka River Basin series (Yakutia)}

An investigation of Quaternary deposits of the lower course of the river Indigirka and its tributaries has been carried out on material coll. 1960 by Yu. A. Lavrushin (Geol. Inst. Acad. Sci., USSR).

\section{Mo-226. River Indigirka}

Wood, right side of the $\mathrm{r}$. Indigirka, $80 \mathrm{~km}$ above the settlement Ozhogino $\left(69^{\circ} 50^{\prime} \mathrm{N}\right.$ Lat, $147^{\circ} 30^{\prime} \mathrm{E}$ Long). In a floodplain, terrace height ca. $2 \mathrm{~m}$, aleurites, apparently $1 \mathrm{~m}$ thick, were overlain by fine sand, $1.1 \mathrm{~m}$ thick. Sample was taken from a depth of $1.2 \mathrm{~m}$ in the upper part of mort-lake alluvium sediments. The spore-and-pollen spectra of deposits from this section are similar to the spectrum of the recent vegetation of this region. The supposed age of the $r$. Indigirka low floodplain is the end of the Holocene (Sub-Atlantic period), continuing to the present time.

\section{Mo-227. River Indigirka}

$4125 \pm 180$

Wood, left side of the $\mathrm{r}$. Indigirka, $0.8 \mathrm{~km}$ below the beginning of the branch Poloustnaya (69 $20^{\prime} \mathrm{N}$ Lat, $147^{\circ} 20^{\prime} \mathrm{E}$ Long), in the $4.5-\mathrm{m}-$ high floodplain section of the r. Indigirka. The terrace section is composed of dirty-brown fine sands. The sample, a piece of driftwood, was found in the lower quarter of the stratum, $0.5 \mathrm{~m}$ above water line. The supposed age is Sub-Boreal.

\section{Mo-228. River Indigirka}

$$
2100 \pm 160
$$

150 B.C.

Peat, left side of the r. Indigirka, $0.85 \mathrm{~km}$ below the beginning of the Poloustnaya branch $\left(69^{\circ} 20^{\prime} \mathrm{N}\right.$ Lat, $147^{\circ} 20^{\prime} \mathrm{E}$ Long), the same section of the r. Indigirka high floodplain as Mo-227. Downstream the terrace surface declines toward a river laida filled up with sediments, the section of which from bottom to top is the following: $1.5 \mathrm{~m}$ aleurites, $1.0 \mathrm{~m}$ peat. The sample was taken from the middle part of the peat and dates the end phases of the laida formation as well as the r. Indigirka high floodplain. The supposed age is the end of the Sub-Boreal time.

\section{Mo-229. River Bolshaya Ercha}

$4770 \pm 280$

Birch wood, from section of a high floodplain of the river B. Ercha (tributary of Indigirka), left side, ca. $50 \mathrm{~km}$ from the mouth $\left(69^{\circ} 45^{\prime} \mathrm{N}\right.$ Lat, $148^{\circ} 45^{\prime} \mathrm{E}$ Long). The terrace height is $4.0 \mathrm{~m}$. The formation of this terrace is of the same age as the formation of the lower part of the r. Indigirka high floodplain. From bottom to top were exposed: sands with a maximum thickness $1.5 \mathrm{~m}$, then alternating thin beds of darkbrown peat and dark-grey aleurites, $1.3 \mathrm{~m}$ thick. Sample was taken in the lower part of the stratum ( $1 \mathrm{~m}$ above water-line) where bark and small trunks of tree birches were found. Under this stratum occurs a layer of aleurites 0.4 to $0.5 \mathrm{~m}$ thick, and a peat layer, 0.4 to $0.5 \mathrm{~m}$ thick. The 
sample characterizes the time of a climatic optimum in the Holocene. The supposed age is the Atlantic time.

\section{Mo-230. River B. Ercha}

Alder wood from the same section as Mo-229, from the upper part of the same stratum, where vertically standing alder trunks were met. The sample characterizes the end of the formation of the $r$. Bolshaya Ercha high floodplain. The supposed age is the Atlantic time.

\section{Mo-231. River Indigirka}

$2285 \pm 160$

Larch wood, from section of the first terrace on the right side of the r. Indigirka, $14 \mathrm{~km}$ above the settlement Khaiagystakh $\left(69^{\circ} 50^{\prime} \mathrm{N}\right.$ Lat, $147^{\circ} 30^{\prime} \mathrm{E}$ Long). Terrace height is $15 \mathrm{~m}$. The sample was taken at a depth of $12 \mathrm{~m}$ where remains of an arborescent vegetation were met. The supposed age of the deposits is the time of the last (Zyryansk) glaciationthe end of the Upper Pleistocene. Comment: the discrepancy between the obtained and expected age may be accounted for by the fact that the sampling place is exposed to the action of flood water, which can emplace younger driftwood into terrace deposits.

\section{Mo-232. River Indigirka}

$8670 \pm 270$ 6720 B.c.

Birch wood, right side of the $\mathrm{r}$. Indigirka, $6 \mathrm{~km}$ below the sovkhoz Shamanovo $\left(69^{\circ} 55^{\prime} \mathrm{N}\right.$ Lat, $147^{\circ} 30^{\prime} \mathrm{E}$ Long). At this locality, on the surface of the first terrace there is a sunken lake basin which is partly filled with lacustrine sediments. At the base of these deposits, at ca. $4 \mathrm{~m}$ depth, remains of a tree birch were found. The sample characterizes the beginning of the climatic optimum of the Holocene. The supposed age is the Atlantic time.

\section{Mo-245. River Indigirka}

$6850 \pm 225$

Larch wood taken from the middle part of the same lacustrine deposit as Mo-232, at ca. $2.3 \mathrm{~m}$ depth.

\section{Mo-233. River Berelikh}

$7820 \pm 210$

Alder wood from the basal layer of lacustrine (alassy) deposits which partly fill the thermokarst sink on the surface of the alluvial lacustrine plain of the Primorye lowland, right side of the $\mathrm{r}$. Berelikh (tributary of the $\mathrm{r}$ Indigirka), $4 \mathrm{~km}$ below the channel Omuk-Saene $\left(70^{\circ} 30^{\prime} \mathrm{N}\right.$ Lat, $147^{\circ} 00^{\prime} \mathrm{E}$ Long). Sampling depth is $5.9 \mathrm{~m}$. The supposed age is the climatic optimum of the Holocene.

\section{Mo-234. River Berelikh}

$7850 \pm 250$

5900 B.C.

Birch wood, at the same place as Mo-233 from a depth of ca. $6.0 \mathrm{~m}$. The supposed age is the climatic optimum of the Holocene. Comment: 
according to the present sample series the climatic optimum of the Holocene on the territory of the NE of the USSR took place approx. 9000 to $4500 \mathrm{yr}$ ago (Mo-232, Mo-229). This may be compared with analogous events in Western Europe and Alaska and permits one to synchronize the chief stages of the Holocene almost over the whole northern hemisphere (Lavrushin, Devirts, Gitterman and Markova, 1963).

\section{Other Geological Samples}

\section{Marine sediments of the Black Sea}

During the 32nd cruise of the ship Vityaz in 1960 V. A. Grinenko (V. I. Vernadsky Inst. of Geochemistry) coll. sea oozes from the Black Sea bottom in order to study the isotopic sulphur composition. Ooze cores from bottom deposits were selected along the vertical section on the ship moorings. In some cores the ooze samples contained an amount of organic matter sufficient for age determination by $\mathrm{C}^{14}$. The ooze samples were as far as possible selected on the boundary of neoeuxinic and old Black sea sediments.

\section{Mo-283. Black sea}

$8000 \pm 260$

6050 B.C.

Ooze from the Black sea bottom, station 4745-2, slope near Batumi ( $41^{\circ} 40^{\prime} \mathrm{N}$ Lat, $40^{\circ} 32^{\prime} \mathrm{E}$ Long). The sea depth in the sampling place is $1704 \mathrm{~m}$, the sampling depth below bottom is 160 to $180 \mathrm{~cm}$. The sample material consists of an interstratification of homogenous clayey ooze with microlaminated clayey sapropel-like ooze. Below $190 \mathrm{~cm}$ begin sediments of the neoeuxinic time.

\section{Mo-344. Black sea}

$23,000 \pm 1320$

Sapropelic, brown, microlaminated ooze with a $\mathrm{H}_{2} \mathrm{~S}$ smell from the same station as Mo-283. The sample was taken from 680 to $710 \mathrm{~cm}$ depth below bottom.

Mo-284-A. Black sea

$$
7225 \pm 250
$$

Sapropelic, brown, microlaminated ooze with a $\mathrm{H}_{2} \mathrm{~S}$ smell. Station 4740 , near the Crimean shore ( $43^{\circ} 51^{\prime} \mathrm{N}$ Lat, $33^{\circ} 38^{\prime} \mathrm{E}$ Long). The sea depth is $2044 \mathrm{~m}$, the sampling depth below bottom is 339 to $352 \mathrm{~cm}$.

\section{Mo-284. Black sea}

$7510 \pm 240$

The same core as Mo-284-A, but the sampling depth is 352 to 365 $\mathrm{cm}$. The sample lies on a clay of neoeuxinic age.

$5040 \pm 195$

Mo-286. Black sea

3090 B.c.

Microlaminated, greenish-gray, soft clay. Station 4754-5. Slope of the Bosporus coast $\left(43^{\circ} 34^{\prime} \mathrm{N}\right.$ Lat, $29^{\circ} 22^{\prime} \mathrm{E}$ Long). The sea depth at the sampling place is $1193 \mathrm{~m}$, the sampling depth in core 115 to $140 \mathrm{~cm}$. 
Sample dates the end of the old Black-sea period. The supposed age is ca. $3000 \mathrm{yr}$.

\section{Mo-287. Black sea}

$9350 \pm 220$

7400 B.C.

The same as Mo-286. The deth in core is 435 to $458 \mathrm{~cm}$. At date of this sample the Old Black-sea period began. Stratigraphically, sample is connected with samples Mo-283 and Mo-284. The end of the neoeuxinic stage and the beginning of the Old Black-sea time is dated by different investigators as belonging to the time-interval from 12,000 to $5000 \mathrm{yr}$ ago. Comment: from the data on the sulphur isotope study and the $\mathrm{C}^{14} \mathrm{de}$ termination in organic matter (Mo-283, Mo-284, Mo-287) it was possible to establish that ca. $8000 \mathrm{yr}$ ago the fresh-water basin of the Black sea began to fill up with sea water from the Sea of Marmora by way of the Bosporus strait. Thus the time of the beginning of the recent hydrogen sulfide contamination of the Black sea was outlined (Vinogradov, Grinenko and Ustinov, 1962).

\section{The Arctic}

Sample finds of organic origin beyond the polar circle are rather rarely met. Datings of such finds by $\mathrm{C}^{14}$ are of exceptional value for the study of the history of the Soviet Arctic islands, especially, taking into account that usual paleobotanic methods are of no use in the present case. All samples (except one) are driftwood, cast ashore by the sea and buried by later deposits. Only in one case was autochthonous material found, i.e., peat which had not been subjected to transport and redeposition (Mo355). All samples were subm. by M. G. Grosswald (Geog. Inst. of the Acad. of Sci., USSR).

\section{Mo-195. Island Hooker}

$7450 \pm 135$

\section{B.c.}

Marine driftwood, Franz Josef Land, Isl. Hooker, Cape Dandy $\left(80^{\circ}\right.$ $20^{\prime} \mathrm{N}$ Lat, $52^{\circ} 40^{\prime} \mathrm{E}$ Long). The sample was broken off from the end of a tree trunk buried by rubbly-pebbly deposits exposed in sea cliff, $26 \mathrm{~m}$ high. The pebble beds have an undisturbed marine lamination. The sample was taken at a depth of 10 to $30 \mathrm{~cm}$ from the diurnal surface level. According to the terrace height above sealevel and the average rate of isostatic uplift ( 0.5 to $1.0 \mathrm{~m} / 100 \mathrm{yr}$ ) in the region of former glaciation the supposed age is 5000 to 10,000 yr. The sample was taken by M. G. Grosswald in 1959.

\section{Mo-239. Island Hayes}

$4775 \pm 115$ 2825 B.C.

Marine driftwood, Franz Josef Land, Isl. Hayes $\left(80^{\circ} 30^{\prime} \mathrm{N}\right.$ Lat, $57^{\circ}$ $00^{\prime}$ E Long). Surface of a sea terrace, $10 \mathrm{~m}$ high above the sealevel. The sample, imbedded in the terrace surface, has partly been carried in by marine sands. The supposed age is 4000 to $5000 \mathrm{yr}$. The sample was coll. 1960 by L. S. Govorukha (Arctic and Antarctic Sci. Research. Inst.). 
Mo-258. Island Victoria

1020
A.D. 930

Marine driftwood, Island Victoria (western sector of the Soviet Arctic) $\left(80^{\circ} 10^{\prime} \mathrm{N}\right.$ Lat, $37^{\circ} 00^{\prime} \mathrm{E}$ Long). The sample was taken from the surface of a marine terrace near the Cape of Knipovich at a height of $5.5 \mathrm{~m}$. The driftwood had melted out from under the ice cap in summer 1961 and was coll. by L. S. Govorukha. The supposed age is the boundary between the Later and the Middle Holocene.

\section{Mo-355. Island Alexandra Land}

$5500 \pm 235$

3550 B.C.

Peat from sea weeds, Franz Josef Land, Island Alexandra Land, Cape Nagurski $\left(80^{\circ} 50^{\prime} \mathrm{N}\right.$ Lat, $48^{\circ} 00^{\prime} \mathrm{E}$ Long). The sample was taken at a depth of 20 to $30 \mathrm{~cm}$ from the surface of the sea terrace in a depression between low beach barriers. The absolute height of the sampling place is $17.5 \mathrm{~m}$. The peat is in primary position, the possibility of its redeposition being excluded. During a long time the peat was submitted to the influence of permafrost. There is no recent vegetation on the peat surface. The supposed age is ca. $6000 \mathrm{yr}$. The sample was coll. 1961 by V. L. Sukhodrovski.

General Comment: all dates, excluding Mo-258, apply to the islands of the Franz Josef Land archipelago. In spite of the different character of the material it is possible to draw a general conclusion of a very rapid glacioisostatic uplift of the crust of the earth in this region during the late-glacial and postglacial time. This sample ages permit one to conclude that all terraces known on the islands of the archipelago have formed in the Holocene, while earlier the highest terraces were thought to date from the time of the Pre-Zyryansk interglacial period (Grosswald, Devirts, and Dobkina, 1961, 1963, 1964). The obtained datings are correlated with datings previously obtained in the laboratory of the Uppsala Univ. (Sweden) (Olsson, 1960) for islands of the adjacent Spitsbergen archipelago and show the synchronous and common character of the climatic changes in postglacial time in this part of the Arctic region.

\section{Kamchatka}

The territory of Kamchatka is characterized by the presence of a great number of active and extinct valcanoes. The present samples are related to the activity of two volcanoes: Khangar and Shiveluch.

\section{Mo-169. Voleano Khangar}

$$
6460 \pm 135
$$

Wood, a birch trunk fragment taken in a pumice terrace of the middle course of the $r$. Kheivan in the region of the Middle Mountain Range of Kamchatka (54 $45^{\prime} \mathrm{N}$ Lat, $157^{\circ} 30^{\prime}$ E Long). Fragments of charred wood are found among loose pumice deposits ejected by the volcano Khangar. On the basis of an assumption concerning the dacite cone formation of the Khangar in the postglacial period, the supposed 
sample age is also postglacial (Marenina, 1959). The sample was coll. 1948 by A. E. Svyatlovski (Lab. of Volcanology, Acad. Sci., USSR).

Mo-129. Volcano Shiveluch

$1500 \pm 170$

Part of a burnt log of wood from a pumice layer of an ancient ejection of the volcano Shiveluch below a moraine of the last glaciation; it was found near the volcano itself $\left(56^{\circ} 45^{\prime} \mathrm{N}\right.$ Lat, $161^{\circ} 30^{\prime} \mathrm{E}$ Long). Coll. 1955 and subm. by G. S. Gorshkov (Lab. of Volcanology, Acad. Sci., USSR). The supposed age is 10,000 to $12,000 \mathrm{yr}$.

\section{Mo-130. Klyuchi}

$3100 \pm 200$

Charcoal from the hearth of an ancient Kamchadal site in the region of the settlement Klyuchi $\left(56^{\circ} 20^{\prime} \mathrm{N}\right.$ Lat, $161^{\circ} 00^{\prime} \mathrm{E}$ Long). The sample was taken at a depth of $2.7 \mathrm{~m}$ from the surface. The deposits are covered by some layers of ash and sand from the gigantic ejections of the volcano Shiveluch. Coll. 1955 and subm. by G. S. Gorshkov. The supposed age is ca. $1000 \mathrm{yr}$.

\section{Lake Ushkovskoye series}

Samples of burnt wood from the coast of the lake Ushkovskoye located on the right side of the r. Kamchatka, 25 to $30 \mathrm{~km}$ below Kozyrevsk $\left(56^{\circ} 15^{\prime} \mathrm{N}\right.$ Lat, $160^{\circ} 10^{\prime} \mathrm{E}$ Long). The samples were coll. 1962 by $\mathrm{N}$. $\mathrm{N}$. Dikov (Siberian branch of the Acad. of Sci., USSR).

\section{Mo-353. Lake Ushkovskoye}

$$
220 \pm 145
$$

Charcoal from cultural deposits of a fisher site. The coal was coll. from subturfic humified loam containing remains of a material culture (stone and bone artifacts, house-hold pits and hearths). The coal bedding depth is $25 \mathrm{~cm}$ from the surface, over the ashes of the volcano Shiveluch, the height of the first terrace is $4 \mathrm{~m}$. By a comparative-typological method this cultural layer (of the Later Neolithic stage) is only approx. estimated to date in the range from the first millennium B.c. to the beginning of the first millenium A.D.

\section{Mo-354. Lake Ushkovskoye}

$2070 \pm 190$

Charcoal from a cultural layer of a Neolithic site at the same place as Mo-353, but at a depth of $1 \mathrm{~m}$ from the surface, among the ashes of the volcano Shiveluch. The sample was coll. from a loam layer containing remains of a burnt wooden ceiling of an ancient pithouse. By a comparative-typological method it is approx. established that the given cultural layer (of the Middle Neolithic stage) dates from the 2nd millenneum B.c. 


\section{Mo-345. Lake Ushkovskoye}

$10,365 \pm 350$

8415 B.C.

Charcoal from a hearth pit. The sample was taken from the same place as Mo-353 and 354, but at a depth of $1.7 \mathrm{~m}$. It was taken in a cultural layer containing stone artifacts of Mesolithic aspect, in yellow laminated loam under ash deposits of the volcano Shiveluch. The general thickness of the loose deposits is about $2 \mathrm{~m}$. The supposed age is ca. 10,000 yr. Comment: the sample was suspected to be of Mesolithic age, as it is; it is the most ancient proof of the peopling of Kamchatka.

General Comment: B. I. Piip dates the whole series of Shiveluch ashes from the 2nd millennium A.D. However, samples Mo-354 and Mo-345, found below the chief ash layers of the Shiveluch, force us to deny such an estimation, which was based on the thickness of loose deposits enclosing the ashes (Piip, 1948).

II. ARCHAEOLOGIC SAMPLES

\section{Khorezm Expedition series}

The material of the finds was collected during the excavations of the Khorezm cooperative archaeological-ethnographical expedition of the Acad. of Sci., USSR in Middle Asia in 1953-59. All samples were studied by archaeologists and estimated on the basis of archaeological complexes including well datable objects: arrow-heads, ceramic artifacts, working tools, etc. The samples were subm. by the head of the expedition, correspond.-memb. Acad. of Sci., USSR, S. P. Tolstov (MiklukhoMaklai Inst. of Ethnography, Acad. of Sci., USSR). All material presented here was obtained from sites located by the Khorezm expedition in the lower part of the r. Amu-Darya basin and in the zone of dry branches of the r. Syr-Darya ancient delta (Tolstov, 1961).

\section{Mo-91. Khorezm}

$1855 \pm 130$

\section{A.D. 95}

Charcoal, Kanga-kala (Karakalpakian Auton. Sov. Soc. Republ.). Central building, No. 1. Taken in 1955. The supposed age is the 4th century A.D. Comment: the cited figure is the average of two determinations made in different counters.

\section{Mo-96. Khorezm}

$2090 \pm 180$

Charcoal, Koi-Krylgan-kala, eastern sector, room 13-B, pit No. 7. Taken in 1955. The supposed age is 4 th to 2 nd centuries B.c.

\section{Mo-99. Khorezm}

Charcoal from a burnt layer, left bank of Khorezm, NE Kara-Kumy, Turkmenian SSR. Site of the ancient town Kalaly-gyr I, palace building, room No. 1. The sample was taken in 1953. The supposed age is the 4 th to 3 rd centuries B.c. 
Mo-100. Khorezm

$1840 \pm 130$

Charcoal, Kalaly-gyr, Tower 15 at the entrance into the furnace of the large (lower) kiln. Taken in 1953. The supposed age is the 2nd to 3rd centuries A.D. Comment: the cited age is an average of two determinations made at different times.

\section{Mo-104. Khorezm}

$2145 \pm 100$

Charcoal, right bank of Khorezm, Karakalpakian Auton. Sov. Soc. Republ., environs of Adamli-kala, point 13/70. The sample was taken in 1953. The supposed age is 4 th to 3 rd centuries B.C.

\section{Mo-172. Khorezm}

$2965 \pm 100$

Fragments of a wooden beam, North Kzyl-Kumy, Kazakh SSR, KzylOrdinsk region, site of the ancient town Babish-mulla I, big house, room No. 5 between floor 2 and 3. Stratigraphic conditions: in loose ground, not more than $30 \mathrm{~cm}$ from the surface. The samples were taken in 1959 . The supposed age is 4 th to 3 rd centuries B.c.

\section{Mo-174. Khorezm}

$2505 \pm 100$

Charcoal, right bank of Khorezm, Karakalpakian Auton. Sov. Soc. Republ., site Yakke-persan 2, house No. 8 (half-dug-out). Found on an earth floor, in cultural layer mixed with sandy-loam, $0.8 \mathrm{~m}$ from the recent surface. The sample was taken in 1959. The supposed age is the 9 th to 8 th centuries B.c.

\section{Mo-175. Khorezm}

$3075 \pm 100$

1125 B.c.

Charcoal, northern Kzyl-Kumy, Kazakh SSR, Kzyl-Ordinsk province, Tagisken, burial ground, sepulchral erection No. 7. Found in the central part of the burial, along the wall, 15 to $20 \mathrm{~cm}$ from the recent surface. The sample was taken in 1959. The supposed age is 9th to 8th centuries B.C.

\section{Mo-193. Khorezm}

$3075 \pm 100$

Charcoal, left bank of Khorezm, northern Kara-Kumy, Turkmenian SSR. Site of the ancient town Kyuseli-gyr, digging VI, room No. 1. From a hearth under a clay layer, 0.3 to $0.5 \mathrm{~m}$ thick. The sample was taken in 1954. The supposed age is the 6 th to 5 th centuries B.c.

Mo-194. Khorezm

Charcoal, northern Kzyl-Kumy, Kazakh SSR, Kzyl-Ordinsk province. Site of the ancient town Chirik-rabat, digging III, round sepulchral erection, passage from room No. 1 into room No. 4. Found in sockets of the 
framework of the clay wall-coating. The sample was taken in 1958. The supposed age is the 4th century B.c.

Comment: in the investigated series of 10 samples most (8) of the datings approx. agree with the estimations of archaeologists (within limits of error of the method, including that from synthesis of counting gases and from measurement of $\mathrm{C}^{14}$-activity). Two samples, Mo-172 and Mo193 , give a great discrepancy (600 to $700 \mathrm{yr}$ too old) between archaeological estimations and dates according to $\mathrm{C}^{14}$. The reason for such discrepancies may be that trees which had perished long before use could be employed as building material and fuel.

\section{Mo-1. Peat-bog Gorbunovsky, section 6}

$4360 \pm 200$

2410 B.c.

Wood of a fossil tree from a site on the 6th section of the Gorbunovsky peat-bog near the town Nizhni Tagil in the Sverdlovsk province $\left(57^{\circ} 55^{\prime} \mathrm{N}\right.$ Lat, $60^{\circ} 00^{\prime} \mathrm{E}$ Long). On this site 2 cultural layers are well traceable and a 3rd cultural layer in the upper horizons is outlined. The sample was selected from the lower layer at a depth of 2.0 to $2.5 \mathrm{~m}$ during excavations carried out in 1949 by A. Ya. Bryusov and V. M. Rauschenbach (Hist. State Mus.) and subm. by the correspond. memb. Acad. Sci., USSR, B. A. Rybakov. On the basis of an analysis of the archaeological material the lower (dated) layer dates from the end of the 3rd to the beginning of the 2nd millennium B.c. (Rauschenbach, 1956).

$4800 \pm 200$

Mo-2. Peat-bog Gorbunovsky, Strelka

2850 B.c.

Wood of a fossil tree from the site Strelka in the $\mathrm{N}$ part of the peatbog Gorbunovsky near the town Nizhni Tagil in the Sverdlovsk province. The site is single-layered. The sample was taken from the cultural layer which can be traced in the peat from a depth of $63 \mathrm{~cm}$ in the main peat body downward until sapropel is encountered at a depth of $95 \mathrm{~cm}$. The sample was selected by A. Ya. Bryusov and V. M. Raucshenbach and subm. by the corresp. memb. B. R. Rybakov. The cultural layer of the site Strelka is stratigraphically somewhat older than the lower layer of the 6th section (Mo-1, above), and from analysis of archaeological complexes was estimated as belonging to the middle of the 3rd millennium B.c. (Rauschenbach, 1956).

Mo-11. Molodova, Ukraine

$23,000 \pm 800$

21,050 в.C.

Charcoal from remains of camp-fires of Upper Paleolithic man. The sample was taken from the 7 th cultural horizon on a multi-layer Paleolithic site of Molodova V in the middle Dnestr foreland near the village Molodova of the Kelmenetsk district in the Chernovitsy province, Ukraine $\left(48^{\circ} 30^{\prime} \mathrm{N}\right.$ Lat, $26^{\circ} 00^{\prime} \mathrm{E}$ Long). The Paleolithic layer from which the sample was taken is located in loess-like loams with feeble traces of soil formation at a depth of ca. $3.5 \mathrm{~m}$ from the surface. Accord- 
ing to geological data the sampled deposit belongs to the Upper Pleistocene, the middle Würm $\left(Q_{3}\right)$. Archaeologically similar cultural layers were dated in Western Europe (in Czechoslovakia and France) by the radiocarbon method; results obtained were in the range of 25,000 to $26,000 \mathrm{yr}$. The sample was coll. 1956 from a type stratigraphic section and subm. by I. K. Ivanova (Comm. for the Inv. of the Quaternary Period, Acad. of Sci., USSR) (Ivanova, 1959; Ivanova and Chernysh, 1963). Comment: the age of a charcoal sample from the same (7th) cultural horizon of the same site was determined by the scintillation method in the Lab. of absolute age, Geol. Inst. Acad. Sci., USSR. Datings of $23,950 \pm 980$ and 23,680 $\pm 400 \mathrm{yr}$ have been obtained (Alekseev, Ivanova, Kind, and Chernysh, 1964).

\section{Mo-176. Armenia}

$1700 \pm 100$

Wood, part of an ancient mine timbering, Armenian SSR. The sample was found in 1959 during new prospecting borings at a depth of $100 \mathrm{~m}$ from the surface. Subm. by Sh. O. Amiryan (Geol. Inst. Acad. Sci., Armen. SSR). The supposed age is the 1lth to 9 th centuries B.C. or 7 th to 8th centuries A.D. Comment: the obtained age characterizes the period of the first gold deposit exploitation on the territory of Armenia.

\section{Mo-334. River Naryn, Kirgizia}

$1680 \pm 170$

Coal from the cultural layer on the left side of the r. Naryn (Kirgizian SSR), $3 \mathrm{~km} \mathrm{E}$ of the mouth of the $\mathrm{r}$. Alabuga $\left(41^{\circ} 25^{\prime} \mathrm{N}\right.$ Lat, $74^{\circ}$ $40^{\prime} \mathrm{E}$ Long). The sample was found at a depth of $7.6 \mathrm{~m}$ in the form of scattered coals in a loamy rock in deposits of a $26-\mathrm{m}$ terrace. According to archaeological estimations the sample dates from the 5th to 7 th centuries A.D. The sample was found by K. V. Kurdyumov (Moscow State Univ.) in 1962. Comment: the find serves as a verification of archaeological data on the peopling of the Tien-Shan.

\section{Mo-343. River Yenisei, Krasnoyarsk}

$11,335 \pm 270$

Charcoal from the site Afontova Gora II, left side of the $\mathrm{r}$. Yenisei near the town Krasnoyarsk $\left(56^{\circ} 00^{\prime} \mathrm{N}\right.$ Lat, $92^{\circ} 50^{\prime} \mathrm{E}$ Long). The sample was taken in an outcrop between the lower and middle layers of a Paleolithic site at a depth of 6 to $8 \mathrm{~m}$ from the surface. According to archaeological estimations the supposed age is the middle of the second half of the Later Paleolithic, i.e., 15,000 to 25,000 B.P. The sample was coll. 1961 and subm. by S. I. Rudenko and S. N. Astakhov (Archaeol. Inst. of the Acad. of Sci., USS). Comment: by reason of the small number of samples no preliminary chemical treatment was carried out.

\section{FOSSIL ANIMALS}

We know finds of buried carcasses of animals-mammoths not existing today, but well-preserved until now. By dating such finds the prob- 
lem of the extinction time of these animals may be solved. We have analyzed the remains of Taimyr and Chekurov mammoths (Siberia). The age of the Taimyr mammoth was determined in our laboratory just at the beginning of its work by the method of counting solid carbon. A figure of the order of 12 thousand yr was obtained (Vinogradov, 1954). Later the age of fossil wood, found in the mammoth horizon of Taimyr, was determined by the gas method. For the Chekurov mammoth, along with the determination of the age of the hair of the mammoth, an investigation of the peat located $0.5 \mathrm{~m}$ above the mammoth carcass was carried out.

\section{Mo-3. Taimyr}

$11,700 \pm 300$ 9750 B.C.

Wood of a fossil tree (Salix) from the mammoth horizon, N shore of the Taimyr lake, excavations of 1949. Subm. by B. A. Tikhomirov (Komarov Bot. Inst., Acad. of Sci., USSR).

\section{Mo-215. River Lena, Chekurovka \\ $26,000 \pm 1600$ 24,050 B.C.}

Mammoth hair, from carcass found $1.5 \mathrm{~km}$ below the settlement Chekurovka of the Bulunsk region, territory of the river Lena delta $\left(71^{\circ}\right.$ $00^{\prime} \mathrm{N}$ Lat, $127^{\circ} 40^{\prime} \mathrm{E}$ Long). The sample was found in the first terrace at a depth not exceeding $1.5 \mathrm{~m}$ from the surface in the permafrost zone. The specimen is a young female of ca. 2/3 of full-grown mammoth size and has very small tusks. Most of the bones lay in the illuvial-diluvial sandy-argillaceous layer containing rock debris of basal Cambrian limestone. The sample was found in 1960 and subm. independently by $\mathrm{V}$. N. Yakovlev (Univ. of Yakutsk) and S. S. Korzhuev (Geog. Inst. Acad. Sci., USSR). According to the spore-and-pollen diagram of terrace deposits from the mammoth burial site the supposed age of the find is the xerothermic maximum of postglacial time (Korzhuev and Fedorova, 1962).

\section{Mo-215-A. River Lena, Chekurovka}

$5610 \pm 200$

3660 B.C.

Peat from the same section as the mammoth carcass Mo-215, but from a depth of ca. $1 \mathrm{~m}$ (i.e., $0.5 \mathrm{~m}$ above the mammoth carcass). Peat layer, $15 \mathrm{~cm}$ thick, is overlain by loam, $45 \mathrm{~cm}$ thick, with intercalations of decomposed matter; a thin loam $30 \mathrm{~cm}$ thick, underlies the peat. The sample was subm. by S. S. Korzhuev.

Comment: the provisional absolute age of the Taimyr mammoth remains (the tendons were investigated) coincided well with the age of wood from the mammoth horizon. In the case of the mammoth from Chekurovka the mammoth hair and the overlying peat proved to be of different age. The absolute peat age actually falls in the xerothermic period. This allows us to assume that the authors of the mentioned article (Korzhuev and Fedorova, 1962), having correctly estimated the age of the peat deposits, attributed this figure 
also to the mammoth. The obtained datings of the death time of both mammoths agree with the known $\left(\mathrm{C}^{14}\right)$ time range of these animals, which was 47,000 to 11,000 B.P. for six finds of Siberian mammoths dated by R. Nydal in the Lab. of Radioactive Dating of the Phys. Inst. in Trondheim, Norway. The age of the Taimyr mammoth which was obtained in our laboratory coincided particular closely with Nydal's results for the Taimyr mammoth, 11,450 \pm 250 (T-297) and dates from the end of the Sartansk glaciation in Siberia (Heintz and Garutt, 1964).

\section{Mo-255. Antarctic}

$2225 \pm 130$

Shin of a seal mummy, Antarctic, oasis Shirmakhera, $8 \mathrm{~km}$ to the $\mathrm{W}$-NW from the station Novo-Lazarevskaya $\left(70^{\circ} 45^{\prime} \mathrm{S}\right.$ Lat, $11^{\circ} 35^{\prime} \mathrm{E}$ Long). The seal mummy was found on the surface, its lower part buried in sand; the upper part was slightly powdered with small pebbles. The upper part of the carcass was half decayed and the bones were jutting out. On the lower part which was lying in the sand, the pelt was well preserved. The mummy had a slightly curved form and was ca. $1 \mathrm{~m}$ long. The seal mummy was lying on large fragments of moraine on a hilly slope, $200 \mathrm{~m}$ from the $\mathrm{N}$ border of the oasis, at a height of 10 to $15 \mathrm{~m}$ above the surface of the ice adjacent to the oasis. (The oasis Shirmakhera is located at a distance of $80 \mathrm{~km}$ from the recent seacoast and is separated from it by shelf ice.) The slope gently dipped to the oasis border forming an inclined platform ca. 100 by $200 \mathrm{~m}$ which did not hinder the movement of seals. Found in 1961 and subm. by. V. I. Bardin (Moscow State Univ.) (Bardin, 1963). Comment: the age obtained for the seal mummy agrees well with the age of analogous finds from other places of the Antarctic (Péwé, Rivard, and Llano, 1959).

\section{REFERENCES}

Alexeev, M. N., 1957, Contribution to the Pleistocene geomorphology and stratigraphy of the river Vilyui lower reaches: Bull. Komissii po izucheniu chetvertichnogo
perioda, no. 21, p. 87-96.

Alexeev, V. A., Ivanova, I. K., Kind, N. V., Chernysh, A. P., 1964, New data on the absolute age of the Late-Paleolithic layers of the site Molodovo V at the river Dnestr middle course: Doklady Akad. Nauk SSSR, v. 156, no. 2, p. 315-317.

Bardin, V. I., 1963, Mountains of the central part of Queen Maud's Land (Eastern Antarctic): Abstract from Thesis for a candidate's (geog. sci.) degree, Moscow.

Basalikas, A. A., 1957, Principal features of the Lithuanian Soviet Soc. Republic relicf: Nauchnye Soobshchenya Instituta geologii i geografii Ak. Neuk Litovskoi SSR,
Vilnus, v. 4, p. 237-246.

Chebotareva, N. S., Serebryanny, L. R., Devirts, A. L., Dobkina, E. I., 1962, Absolute age of the low river terraces in the centre of the Russian plain: Izvestia Akad.
Nauk SSSR, ser. geograficheskaya, no. 4, p. 70-74.

Chebotareva, N. S., Serebryanny, L. R., 1963, Paleogeographic estimations of radiocarbon dating of the Upper-Quaternary sediments in the Russian plain centre: in Absolute Geochronology of the Quaternary Period, Moscow, Acad. of Sci., USSR, p. $117-122$

Danilans, I. Ya., 1962, Problems of the Pleistocene deposit stratigraphy of Latvia: in Problems of Quaternary Geology, Riga.

Gerasimov, I. P., Chebotareva, N. S., 1963, The absolute age of the last Valdai glaciation in the north-western part of the Russian plain: Izvestia Ak. Nauk SSSR, Seria Geograf., no. 5, p. 36-44. 
Gerasimov, I. P., Serebryanny, L. R., Chebotareva, N. S., 1963, Stratigraphic components of the Pleistocene of Northern Europe and their correlation: in Anthropogene of the Russian Plain and Its Stratigraphical Components, M., Acad. Sci. USSR, p. 5-60.

Godwin, H., Walker, D., Willis, E. H., 1957, Radiocarbon dating and post-glacial vegetational history: Scaleby Moss: Proc. of Royal Soc., ser. B., v. 147, no. 928, p. $352-366$.

Grosswald, M. G., Devirts, A. L., Dobkina, E. I., 1961, About the history of the Holocene of the Franz Josef Land: Doklady Ak. Nauk SSSR, v. 141, no. 5, p. $1175-1178$.

1963, Glacial stages Sedova and Victoria: Materialy glyatsologicheskikh issledovanii, no. 7 , p. 149-151.

- 1964, One more dating of the coast of Franz Josef Land: Materialy glyatsologicheskikh issledovanii, no. 10, p. 273-274.

Gudelis, V. K., 1961, Outline of the geology and paleogeography of the Lithuanian Quaternary period (Anthropogene): in Czwartorzejd Europy Środkowej i Wschodniej, cz. 1, Institut Geologiczny, Prace, t. 34. Warszawa.

Heintz, A. E., Garutt, V. E., 1964, Determination of the absolute age of a fossil mammoth and a woolly rhinoceros remains from the permafrost region of Siberia with the aid of radioactive carbon (C14): Doklady Ak. Nauk SSSR, v. 154, no. 6, p. $1367-1370$.

Ivanova, I. K., 1959, Geological conditions of discovering paleolithic sites in the middle part of the river Dnestr Foreland: Trudy Komissii po izucheniu chetrertichnogo perioda, no. 15 , p. 215.

Ivanova, I. K., Chernysh, A. P., 1963, Absolute age of the Upper Paleolith (Solutrean, Gravettian type) of the river Dnestr Foreland according to data of the radiocarbon analysis: Doklady Ak. Nauk SSSR, v. 148, no. 2, p. 410-413.

Iversen, J., 1953, Radiocarbon dating of the Alleröd pediod: Science, v. 118, no. 3053, p. 9-11.

Khotinsky, N. A., 1964a, Comparison of schemes for a zonal separation of the LateGlacial and the Post-Glacial time with the aid of synchronizing levels: Doklady Ak. Nauk SSSR, v. 156, no. 1, p. 74-77.

1964b, Paleogeography of the Upper Pleistocene and Holocene of the eastern margin of the Upper Volga lowland: Thesis for a candidate's (geog. sci.) degree, Moscow.

Kondratiene, O. P., 1960, Stratigraphy and paleogeography of the Lithuanian NeoPleistocene according to palynologic data: Abstract from Thesis for a candidate's (geol. mineral sci.) degree, Vilnus.

Korzhuev, S. S., Fedorova, R. V., 1962, The mammoth from Chekurovka and its inhabiting conditions: Doklady Akad. Nauk SSSR, v. 143, no. 1, p. 181-183.

Lavrushin, Yu. A., Devirts, A. L., Giterman, R. E., Markova, N. G., 1963, First data on the absolute chronology of the chief events in the north-eastern part of the USSR: Bull. Komissii po izucheniu chetvertichnogo perioda, no. 28, p. 112-126.

Marenina, T. Yu., 1959, The volcano Khangar in the Middle Ridge of Kamchatka: Trudy Laboratorii vulkanologii, no. 17, p. 3-63.

Neistadt, M. I., 1957, History of woods and paleogeography of the USSR in the Holocene: Moscow, Acad. Sci. USSR.

Neistadt, M. I., Devirts, A. L., Markova, N. G., Dobkina, E. I., Khotinsky, N. A., 1962, Dating of the holocenic sediments by the radiocarbon method and according to data of the pollinic analysis: Doklady Ak. Nauk SSSR, v. 144, no. 5, p. 1129-1131.

Nilsson, T., 1964, Standardpollendiagramme und C14-Datierungen aus dem Agcröds Mosse im mittleren Schonen: Publs. from Insts. of Mineralogy, Paleontology and Quaternary Geology, Sweden, no. 124.

Olsson, I., 1960, Uppsala natural radiocarbon measurements, II: Am. Jour. Sci. Radioc. Suppl., v. 2, p. 112-128.

Paleogeography and Chronology of the Upper Pleistocene and Holocene According to Data of the Radiocarbon Method, 1965, ed. by M. I. Neistadt: Moscow, Acad. Sci. USSR.

Péwé, T. L., Rivard, N. R., Llano, G. A., 1959, Mummified seal carcasses in the McMurdo Sound Region, Antarctica: Science, v. 130, no. 3377, p. 716.

Piip, B. I., 1948, New eruptive state of the volcano Shiveluch from the end of 1944 
to May 1945 and some notices on the geological structure of the volcano and its previous eruptions: Bull. vulcanologicheskoi Stantsii na Kamchatke, no. 14.

Rauschenbach, V. M., 1956, The Middle Transurals during the Neolith and Bronze epoch: Trudy Gosud. Istoricheskogo Museya, no. 29.

Seibutis, A. A., 1962, On the stratigraphic significance of the double-layered subsapropelic peaty formations: Trudy Ak. Nauk Litovskoi SSR, ser. B, no. 3, p. $173-178$.

Serebryanny, L. R., Devirts, A. L., Markova, N. G., 1962, New data on the absolute age of the Alleröd sediments in the environs of Leningrad: Bull. Komissii po izucheniu chetvertichnogo perioda, no. 27, p. 151-153.

Serebryanny, L. R., Chebotareva, N. S., 1963, Some debatable problems of paleogeography and stratigraphy of the quaternary sediments in the centre and northwest of the Russian plain (in connection with data of the radiocarbon method) : in Anthropogene of the Russian Plain and Its Stratigraphical Components, Moscow,
p. 74-85.

Tolstov, S. P., 1961, Scythian and Khorezm of the Aral Sea Foreland: Sovetskaya Etnografia, no. 4, p. 114-146.

Velichko, A. A., Devirts, A. L., Dobkina, E. I., Morozova, T. D., Chichagova, O. A., 1964, First determinations of fossil soils in loesses of the Russian plain: Doklady Ak. Nauk SSSR, v. 155, no. 3, p. 355-359.

Vinogradov, A. P., 1954, Geochemistry of isotopes: Vestnik Akad. Nauk SSSR, no. 5, p. 33.

Vinogradov, A. P., Devirts, A. L., Dobkina, E. I., Markova, N. G., Martishchenko, L. G., 1956, Determination of the absolute age according to C14. Communication 1: Geokhimia, no. 8, p. 3-9.

1959 , Determination of the absolute age according to $\mathrm{C}^{14}$. Communication 2 : Geokhimia, no. 8, p. 663-668.

Vinogradov, A. P., Devirts, A. L., Dobkina, E. I., Markova, N. G., 1962, Determination of the absolute age according to C14. Communication 3: Geokhimia, no. 5, p. $387-402$. 4: Geokhimia, no. 9, p. 795-811.

Vinogradov, A. P., Devirts, A. L., Dobkina, E. I., Markova, N. G., Martishchenko, L. G., 1963, Determination of the absolute age according to C14 with the aid of a proportional counter: Moscow, Acad. Sci. USSR.

Vinogradov, A. P., Devirts, A. L., Markova, N. G., Khotinsky, N. A., 1963, Determination of the boundary between the Late-Glacial and the Post-Glacial time according to C14 and data of the spore-pollinic analysis: Geokhimia, no. 11, p. 971-980.

Vinogradov, A. P., Grinenko, V. A., Ustinov, V. I., 1962, Isotopic composition of sulphur compounds in the Black Sea: Geokhimia, no. 10, p. 851-873.

Voznyachuk, L. N., 1959, Conditions of the Riss-Würm deposits in the Grodno province and the adjacent areas of Lithuania and Poland: Vestnik Ak. Nauk Byelorussian Sov. Soc. Rep., Seria fisiko-tekhnicheskikh nauk, no. 4, p. 112. 